\title{
Feasibility study for slope soil stabilization by microbial induced carbonate precipitation (MICP) using indigenous bacteria isolated from cold subarctic region
}

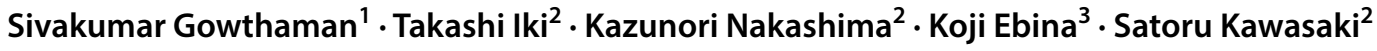

Received: 20 July 2019 / Accepted: 15 October 2019 / Published online: 24 October 2019

(c) Springer Nature Switzerland AG 2019

\begin{abstract}
Microbial induced carbonate precipitation (MICP) is relatively an innovative soil improvement technique, learnt from the bio-mediated geochemical reactions that naturally occur in the earth surface. During the $\mathrm{MICP}, \mathrm{CaCO}_{3}$ is metabolically precipitated in soil pores, cement the particle contacts and improves the strength and stiffness of soil. Environment temperature is one of the most key factors that determines the efficiency MICP. The purpose of this study is to investigate the feasibility of stabilizing the slope soil of cold subarctic region (Hokkaido, Japan). The implication of MICP in cold subarctic zones remains as a major challenge, as the enzymatic performance of the bacteria typically declines during lower temperatures hence insufficient formation of $\mathrm{CaCO}_{3}$ in soil matrix. Therefore, as a potential approach, this study attempted to investigate the feasibility of using the bacteria which have been adapted to native cold climatic conditions. The objectives of this paper are evaluating (1) the effect of temperature in bacterial response, and (2) the effect of grain size distribution in cementation mechanism. The observations suggest that the enzyme activity of the bacteria is negligible at and above $30^{\circ} \mathrm{C}$, whereas it is significant at relatively lower temperatures. The comparison of treated soils suggests that the fine content in slope soil increased number of particle contacts, facilitated effective packing, and promoted the effectiveness of MICP compared to that of uniformly graded sands. Finally, the technical feasibility in slope soil stabilization was well demonstrated using model solidification test. The limitations in stabilizing the slope are also discussed in detail.
\end{abstract}

Keywords Microbial induced carbonate precipitation · Indigenous bacteria $\cdot$ Cold subarctic region · Slope soil · Temperature · Grain size distribution

\section{Introduction}

MICP is an innovative biological ground improvement technique that could be applicable to many geo-engineering problems. The process utilizes the ureolytic bacteria to induce bio-cementation in a sustainable and costeffective manner. The urease enzyme produced by the bacteria catalyses the hydrolysis of urea into ammonium and carbonic acid (Eq. 1), hence increases the alkalinity of the reaction medium. In the presence of calcium ions, the

Electronic supplementary material The online version of this article (https://doi.org/10.1007/s42452-019-1508-y) contains supplementary material, which is available to authorized users.

Sivakumar Gowthaman, gowtham1012@outlook.com; Takashi lki, iki@els.hokudai.ac.jp; Kazunori Nakashima, nakashima@geo-er.eng.hokudai.ac.jp; Koji Ebina, k.ebina.aa@e-nexco.co.jp; Satoru Kawasaki, kawasaki@geo-er.eng.hokudai.ac.jp |

${ }^{1}$ Graduate School of Engineering, Hokkaido University, Kita 13, Nishi 8, Kita-Ku, Sapporo, Hokkaido 060-8628, Japan.

${ }^{2}$ Faculty of Engineering, Hokkaido University, Kita 13, Nishi 8, Kita-Ku, Sapporo, Hokkaido 060-8628, Japan. ${ }^{3}$ Hokkaido office, East Nippon Expressway Company Limited, Atsubetsu-ku, Sapporo, Hokkaido 004-8512, Japan. 
calcium carbonate cement is precipitated at the nucleation sites provided by the bacteria cells (Eq. 2) [1-3].

$$
\begin{aligned}
& \mathrm{CO}\left(\mathrm{NH}_{2}\right)_{2}+2 \mathrm{H}_{2} \mathrm{O} \stackrel{\text { Urease }}{\longrightarrow} 2 \mathrm{NH}_{4}^{+}+\mathrm{CO}_{3}^{2-} \\
& \mathrm{CO}_{3}^{2-}+\mathrm{Ca}^{2+} \stackrel{\text { Bacterial cell }}{\longrightarrow} \text { Cell }-\mathrm{CaCO}_{3} \downarrow
\end{aligned}
$$

The precipitated carbonate crystals coat the soil particles, cement the soil matrix, fill the voids partially, hence increases the desired mechanical properties including strength and stiffness of the soil matrix [4,5]. Despite being a relatively new technique, many MICP studies have been investigated for several geotechnical applications including liquefaction control, erosion mitigation, coastline preservation, sand dunes stabilization, borehole stabilization and settlement control [6-9]. Most of the investigations have been focused on the behavior of MICP treated sand, providing information on the strength and stiffness characteristics under different testing conditions $[2,5,6,9-11]$. The studies to promote MICP applications need to be expanded, for soil types other than sand materials. Few researchers including van Paassen [12] and Mortensen et al. [13] have attempted the investigation on gravel and different soils ranging from very fine to very coarse and suggested that large amount of carbonate precipitation would be required to strengthen the coarsegravel material. Also, the free passage of microorganisms through the limited pore-throat size remains a challenge in treating the very fine soils using MICP [14]. Recently, researchers have started to focus on assessing the performance of MICP in residual soils that consist fine to coarse grains distributed naturally [14-16]. However, only a very limited MICP studies on residual soils have been reported in the literature to the date, providing insufficient information on their mechanical responses.

The MICP treatment can be achieved by stimulating the growth of indigenous bacteria in situ (bio-stimulation) or by augmenting ureolytic bacterial culture (bio-augmentation). Bio-stimulation is a process of modifying the in situ environmental conditions to enrich the existing microbial community with required urease capabilities $[17,18]$. Bioaugmentation largely differs from bio-stimulation and can be enabled by two ways: (1) bio-augmentation of indigenous bacteria: injecting enriched culture of indigenous bacteria isolated from native soil, and (2) bio-augmentation using exogenous bacteria: injecting enriched culture of specialized non-native bacterial strains (e.g. Sporosarcina pasteurii). Bio-augmentation by exogenous bacteria has been extensively researched and demonstrated at a variety of laboratory scales $[1,5,6,11,13]$, whereas the studies concerned on bio-augmentation using indigenous bacteria up to now are very limited $[9,19]$.
The augmentation of indigenous bacteria offers important environmental benefit through the elimination of nonnative bacterial supply (microbial pollution) into natural soil ecosystems [8]. Although the native species perform the urea hydrolysis at slower rates compared to that of specialized strains (e.g. Sporosarcina pasteurii), they would be more reliable than the exogenous strains in their native environment, resulting advantages in MICP with respect to the fitness of the strains and sustained enzymatic capabilities. At the same time, introducing non-native bacteria to a new environment may hinder the survival and enzymatic performance of the strains $[20,21]$, and the process may also face some ambiguities with respect to regulatory acceptance [21].

The selection of suitable ureolytic bacteria is highly important in urease-based MICP technique. The enzymes of the bacteria are thermal sensitive and can readily be denatured by even a slight change of environmental temperature [22]. Most of the MICP studies have employed Sporosarcina pasteurrii for urea hydrolysis due to the highly active urease enzyme [5, 6, 11, 13, 23-25]. Only a few MICP studies focused on introducing some other ureolytic strains including Bacillus sphaercus (MCP-11) [26], Pararhodobactor sp. [9, 27], Bacillus sp.VS1 [28, 29] and B. megaterium (ATCC 14581) [14]. However, most of the soil bacteria reported to date could effectively produce urease enzyme only within moderate to high temperature ranges $\left(25^{\circ} \mathrm{C}-60^{\circ} \mathrm{C}\right)$, and within the range, the activity increased with increase in temperature [14, 30]. It must be noted that the functional temperature range of the enzymatic reaction is required to cover the temperature of the field stratum to be treated for an effective carbonate precipitation. Since the performance of the bacteria becomes negligible at low temperatures, implications of MICP in cold climatic zones remain as a huge challenge.

The study reported herein presents an initial level investigation on stabilization of a residual soil from the slope located in cold subarctic zone (Hokkaido, Japan). The novel indigenous ureolytic bacteria which had been adapted to the cold native environmental conditions were isolated from the native slope soil and investigated in detail. Effect of $\mathrm{CaCO}_{3}$ precipitation on the process of strengthening in slope soil was compared with three uniformly graded soils with distinct mean particle size. The morphology and the spatial distribution of $\mathrm{CaCO}_{3}$ were analysed at the microscale using scanning electron microscopy (SEM). The results obtained from this study would be beneficial to the future work that is to introduce the MICP technique as a novel candidate for surface stabilization of the slope. 


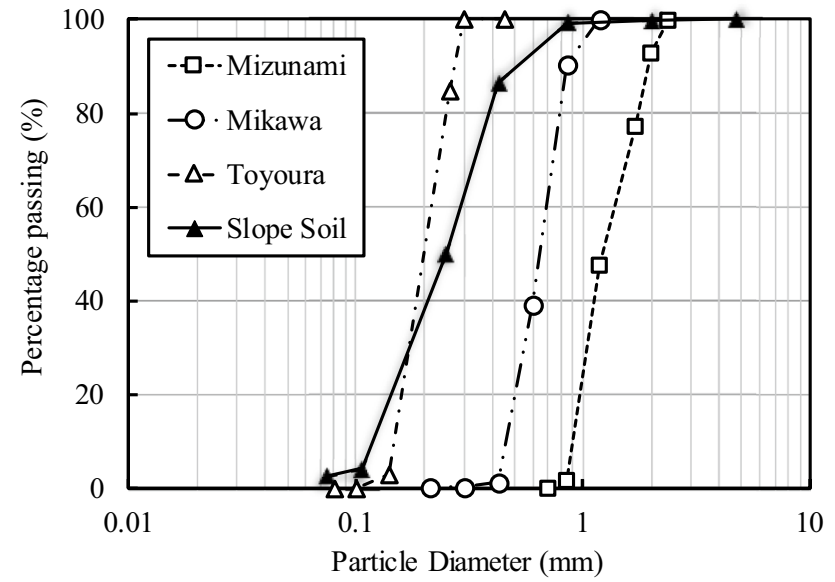

Fig. 1 Grain size distribution curves of sands and slope soil

\section{Materials and method}

\subsection{Soil characteristics}

The grain size distribution curves of the soils studied in this work are given in Fig. 1. Mizunami, Mikawa and Toyoura sands are standard laboratory sands, uniformly graded: SP based on Unified Soil Classification System (USCS) [31] with mean particle sizes $\left(D_{50}\right)$ of $1.6 \mathrm{~mm}, 0.87 \mathrm{~mm}$ and $0.2 \mathrm{~mm}$ respectively. The slope soil considered in the current study is from expressway slope of Onuma, Hokkaido, Japan (Latitude 42.388532 and Longitude 140.284762). It is a well graded sand (SW based on USCS, $D_{50}=0.23 \mathrm{~mm}$ ), consisting very fine sand content (grain size $<125 \mu \mathrm{m}$ ) of $12 \%$. pH value of the slope soil is 6.997 which is very close to that of uniformly graded soils $(7.0 \pm 0.1)$. Similar to the standard sands, the organic content in slope soil is found to be negligible. A summary of the X-Ray diffraction results of all the soils considered herein is presented in Table 1. The results showed that the silica is the dominant mineral in all the soils.

\subsection{Isolation and characterization of indigenous bacteria}

Isolation and characterization of bacteria was performed in accordance with the method suggested in previous studies $[9,32]$. Soil sample collected from the study location (in sterile test tubes) was employed in laboratory for identifying bacteria. $5 \mathrm{~g}$ of soil sample was diluted to $10^{1}-10^{5}$ in separate sterile test tubes with autoclaved distilled water. The solutions were applied on $\mathrm{NH}_{4}-\mathrm{YE}$ agar plates (prepared by combining tris-buffer, ammonium sulfate, yeast extract and ager), followed by the incubation at $30^{\circ} \mathrm{C}$ for $72 \mathrm{~h}$. Formed colonies were then isolated
Table 1 Mineralogical composition of sands and slope soil

\begin{tabular}{|c|c|c|c|c|}
\hline \multirow[t]{2}{*}{ Oxide } & \multicolumn{4}{|c|}{ Percentage (\%) } \\
\hline & Slope soil & Mizunami & Mikawa & Toyoura \\
\hline $\mathrm{SiO}_{2}$ & 57.5 & 97.41 & 97.65 & 92.6 \\
\hline $\mathrm{Al}_{2} \mathrm{O}_{3}$ & 25.6 & 1.37 & 0.89 & 3.7 \\
\hline $\mathrm{Fe}_{2} \mathrm{O}_{3}$ & 8.1 & 0.03 & 0.43 & 0.7 \\
\hline $\mathrm{CaO}$ & 3.68 & - & 0.03 & 0.5 \\
\hline $\mathrm{MgO}$ & 1.99 & - & 0.11 & 0.2 \\
\hline $\mathrm{K}_{2} \mathrm{O}$ & 1.05 & - & 0.18 & - \\
\hline $\mathrm{SO}_{3}$ & 0.672 & - & - & - \\
\hline $\mathrm{TiO}_{2}$ & 0.583 & - & 0.04 & - \\
\hline $\mathrm{P}_{2} \mathrm{O}_{5}$ & 0.302 & - & - & - \\
\hline $\mathrm{MnO}$ & 0.137 & - & - & - \\
\hline $\mathrm{V}_{2} \mathrm{O}_{5}$ & 0.028 & - & - & - \\
\hline $\mathrm{Na}_{2} \mathrm{O}$ & - & - & 0.04 & - \\
\hline
\end{tabular}

and grown on separate new $\mathrm{NH}_{4}-\mathrm{YE}$ agar plates. Each colony was employed in cresol-red test by transferring the colony into $20 \mathrm{~mL}$ cresol-red test solution (combined of cresol-red, urea, ethanol and distilled water), followed by the incubation at $45^{\circ} \mathrm{C}$ for $2 \mathrm{~h}$. The ureolytic bacteria were identified based on the $\mathrm{pH}$ (due to the formation of ammonium ions by hydrolyzing the urea) and color change (from yellow to purple) of the solution. The identified ureolytic strains were characterized by sequencing their $16 \mathrm{~S}$ rDNA and comparing the results to sequences available in the Apollon DB-BA 9.0 database, GenBank, DDBJ (DNA Data Bank of Japan) and EMBL (European Molecular Biology Laboratory).

\subsection{Reactant characteristics}

The bacteria culture was enriched in sterile $\mathrm{NH}_{4}-\mathrm{YE}$ medium consisting tris-buffer (15.7 g/L), ammonium sulfate $(10 \mathrm{~g} / \mathrm{L})$ and yeast extract $(20 \mathrm{~g} / \mathrm{L})$ with a neutral $\mathrm{pH}$ value, aerobically in a shaking incubator at $160 \mathrm{rpm}$. The cementation reagent $(1 \mathrm{~mol} / \mathrm{L})$ for the MICP treatment consisted of calcium chloride $(111 \mathrm{~g} / \mathrm{L})$, urea $(60 \mathrm{~g} / \mathrm{L})$ and nutrient broth $(6 \mathrm{~g} / \mathrm{L})$.

\subsection{Urease activity measurements}

Urease activity of the bacteria was measured using spectrophotometric determination of ammonia as Indophenol [33]. $1 \mathrm{~mL}$ of bacterial culture was added to the $0.1 \mathrm{~mol} / \mathrm{L}$ urea prepared in phosphate buffer solution. The ammonium ions produced from the urea hydrolyses could react with phenol at the presence of hypochlorite and produce the blue colour indophenol dye in the alkaline medium. The intensity of indophenol dye was measured at the wave length of $630 \mathrm{~nm}\left(\mathrm{OD}_{630}\right)$ at different uniform intervals of 
catalysation (at every 5 min interval). Using the calibration curve developed between concentration of ammonium ions and intensity $\left(\mathrm{OD}_{630}\right)$, the rates of urea hydrolysis were estimated.

\subsection{Soil column test}

Soil columns ( $6 \mathrm{~cm}$ in height, $2.5 \mathrm{~cm}$ diameter) were prepared using $35 \mathrm{~mL}$ standard syringes and positioned vertically (Fig. 2). The columns of all the soils were packed to a dry density of $1.6 \pm 0.1 \mathrm{~g} / \mathrm{cm}^{3}$ similar to that reported by Cheng and Cord-Ruwisch [3]. Reactants were injected in two subsequent phases as suggested by several MICP researchers $[1,2,11]$. In the first phase, the enriched bacteria culture was injected to the column followed by a

\section{Two phase injection}

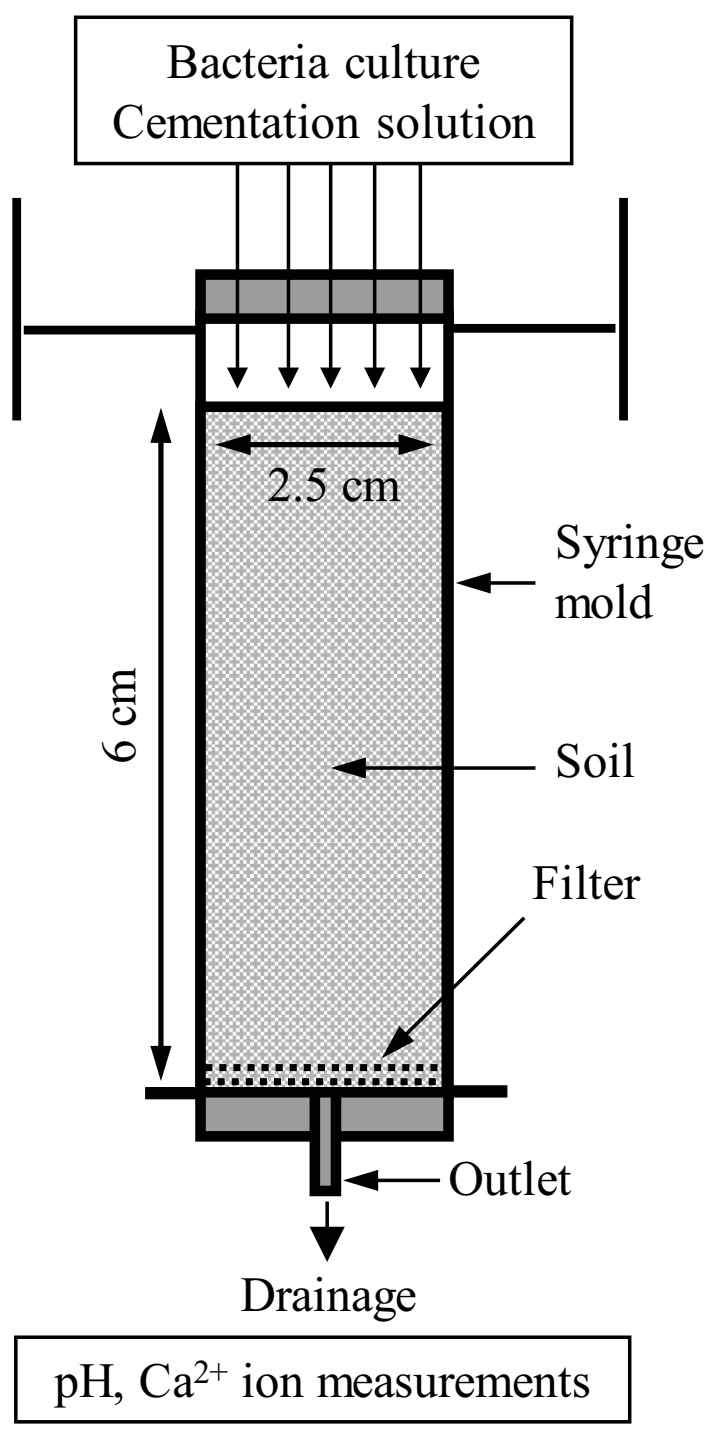

Fig. 2 Schematic diagram of soil column test (experimental set up) time gap of $2 \mathrm{~h}$ to immobilize the bacteria cells with soil particles. In the second phase, cementation solution was injected at a constant flow rate of $2-4 \mathrm{~mL} / \mathrm{min}$. All the solutions were simply applied to the top surface of the soil columns and allowed to percolate under gravitational and capillary forces. During the treatment, the columns were percolated with cementation solution every $24 \mathrm{~h}$ (total of 14 cementation injections, $10 \mathrm{~mL}$ per each), whereas the columns were filled by bacteria culture once again at the middle of the fourteen days treatment period (total of 2 biological injections, $10 \mathrm{~mL}$ per each). The $\mathrm{pH}$ and $\mathrm{Ca}^{2+}$ concentration of the drainage were measured every $72 \mathrm{~h}$. After the treatment was completed, the samples were flushed with distilled water prior to the strength measurements.

\subsection{Slope model test}

The slope model $(13 \times 10 \times 10 \mathrm{~cm})$ was filled with slope soil by five layers, and each layer was compacted evenly to a similar dry density used in column test. The gradient of the slope was resolved to the standard gradient of expressway cut slope in accordance with the road earthwork guidelines of Japan [34, 35]. During the treatment, a grid-based injection method was performed. The slope surface was divided into $8 \times 5$ grids, each grid was $2 \mathrm{~cm} \times 2 \mathrm{~cm}$, and the solutions were injected on the surface of the slope and allowed to percolate under gravitational forces. Based on the pore volume of the soil below each grid, the injection volumes were estimated, and the rate of injection was $8-10 \mathrm{~mL} / \mathrm{min}$. Similar to the column test, 2 number of biological injections and 14 number of cementation injections were performed totally during 14 days of treatment process. The experimental arrangement of slope model test is illustrated in Fig. 3.

\subsection{Uniaxial compressive strength (UCS) measurement}

The UCS of the cemented columns and slope were estimated using needle penetrometer (SH-70, Maruto Testing Machine Company, Tokyo, Japan) according to JGS 3431-2012 [36]. The equipment was developed in Japan for predicting the UCS of soft, weak, very weak rocks and cemented soil specimens, and recently, ISRM has recommended the method for indirect estimation of mechanical properties of the soft rock materials [37]. This penetration is a non-destructive test, and that has a great potential to be used as a sound technique for MICP field assessments. The penetration depth $(\mathrm{mm})$ of the needle attached to the device and the penetration resistance $(\mathrm{N})$ were measured during the test. Using the regression relationship (Eq. 3 ) developed by analyzing 


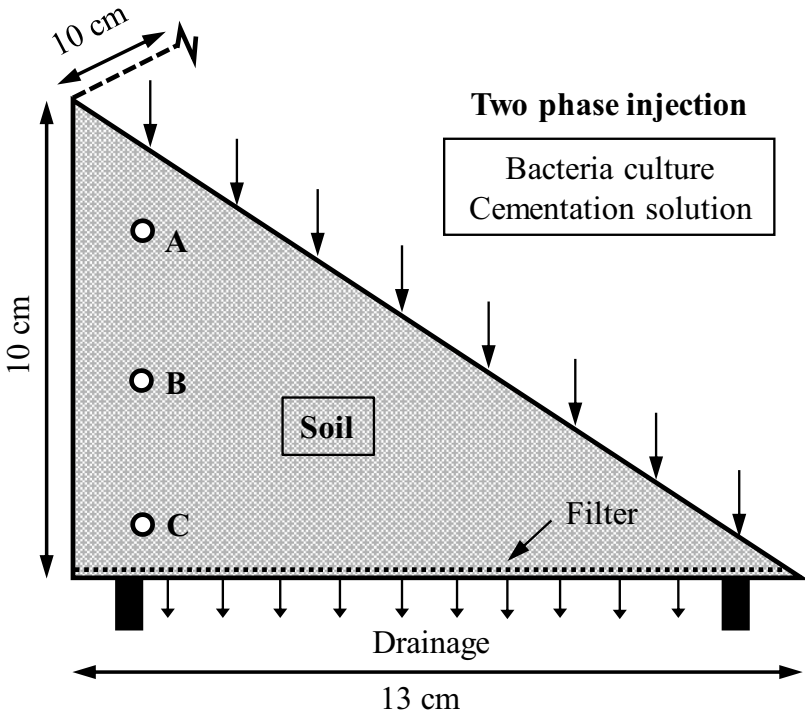

Fig. 3 Schematic diagram of the experimental arrangement of slope model

114 natural soft rock samples and 50 cemented soil samples, the UCS of the specimen was estimated [32, 38].

$\log (y)=0.978 \log (x)+2.621$

where, $x$ is penetration gradient (ration between penetration resistant $(\mathrm{N})$ and penetration depth $(\mathrm{mm})$ ); $y$ is corresponding UCS.

\section{$2.8 \mathrm{CaCO}_{3}$ content determination}

Carbonate content in the treated specimen was determined by using the simplified device developed to measure the pressure of $\mathrm{CO}_{2}$ gas released when the cemented specimen is treated with $\mathrm{HCl}$ in closed system under constant volume and temperature [39]. Cemented column specimen was divided into sections along the height, and the samples from the sections at the depths of $1 \mathrm{~cm}, 3 \mathrm{~cm}$ and $5 \mathrm{~cm}$ (measured from the surface) were carefully separated, ensuring an accurate representation of cemented soil at that depth. Dry mass of the separated sample was measured, and the sample was placed into the calcimeter flask. $20 \mathrm{~mL}$ of $\mathrm{HCl}(3 \mathrm{~mol} / \mathrm{L})$ was placed in small plastic vials and set into the calcimeter flask without spattering the specimen. Subsequently, $\mathrm{HCl}$ was allowed to react with specimen in the closed system until the digital manometer (connected with the system) read a constant pressure. From the calibration curve developed between the pressure and $\mathrm{CaCO}_{3}$ content, the carbonate content was estimated, hence the percentage of mass of $\mathrm{CaCO}_{3}$ was determined.

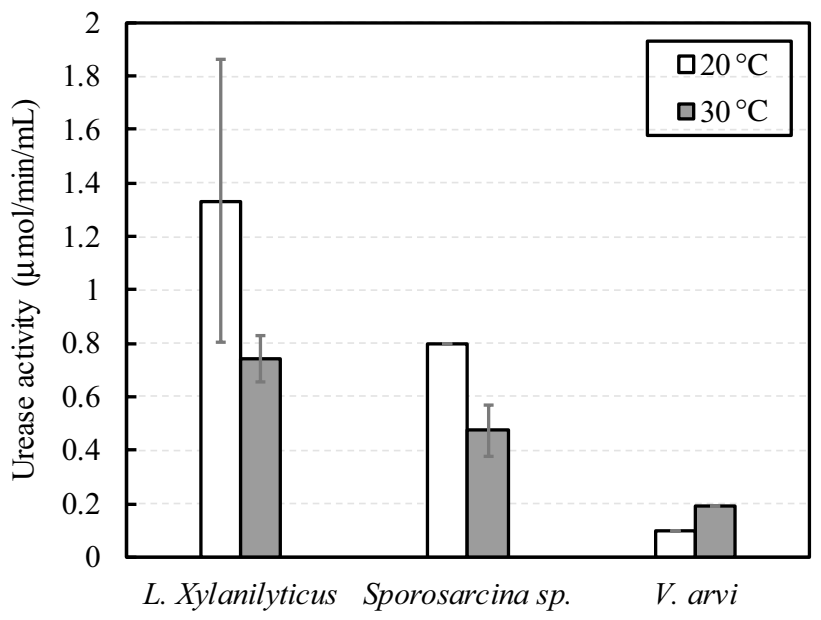

Fig. 4 Urease activity test results of all the bacteria isolated from slope soil. The error bars represent the mean $\pm S D(n=3)$

\section{Results and discussions}

\subsection{Biological response}

\subsubsection{Indigenous isolates}

Among the isolated colonies, only three strains showed the $\mathrm{pH}$ increase and colour change in cresol red indicator, suggesting the urease potential. The strains were characterized as Lysinibacillus xylanilyticus, Viridibacillus arvi and Sporosarcina sp. by the 16S rRNA gene sequence analysis (the authenticate phylograms of the bacteria are presented as supplementary file). From the preliminary experiment results (Fig. 4), Lysinibacillus xylanilyticus culture was chosen based on the highest urease production and investigated in detail for MICP application. Lysinibacillus xylanilyticus is a gram positive, rod shaped bacteria (average length of 8-10 $\mu \mathrm{m}$; diameter of $0.5-0.6 \mu \mathrm{m}$ ). It is worth noting that this is the first paper reporting the urease and MICP potential of the Lysinibacillus xylanilyticus.

\subsubsection{Effect of temperature on growth and urease performance}

Biomass concentration was used as the bacteria growth indicator based on the turbidity of the bacteria culture. The optical density $\left(\mathrm{OD}_{600}\right)$ of Lysinibacillus xylanilyticus culture was measured by using the spectrophotometer at a wave length of $600 \mathrm{~nm}$. The influence of temperature in bacteria growth was investigated by placing the bacteria culture in shaking incubator at temperatures ranging from 10 to $50^{\circ} \mathrm{C}$. The growth curves are presented in Fig. 5. The initial $\mathrm{pH}$ of the culture medium was relatively neutral (7.1-7.3). At the temperatures from 10 to $30^{\circ} \mathrm{C}$, 
Fig. 5 Growth of Lysinibacillus xylanilyticus at different cultivation temperatures

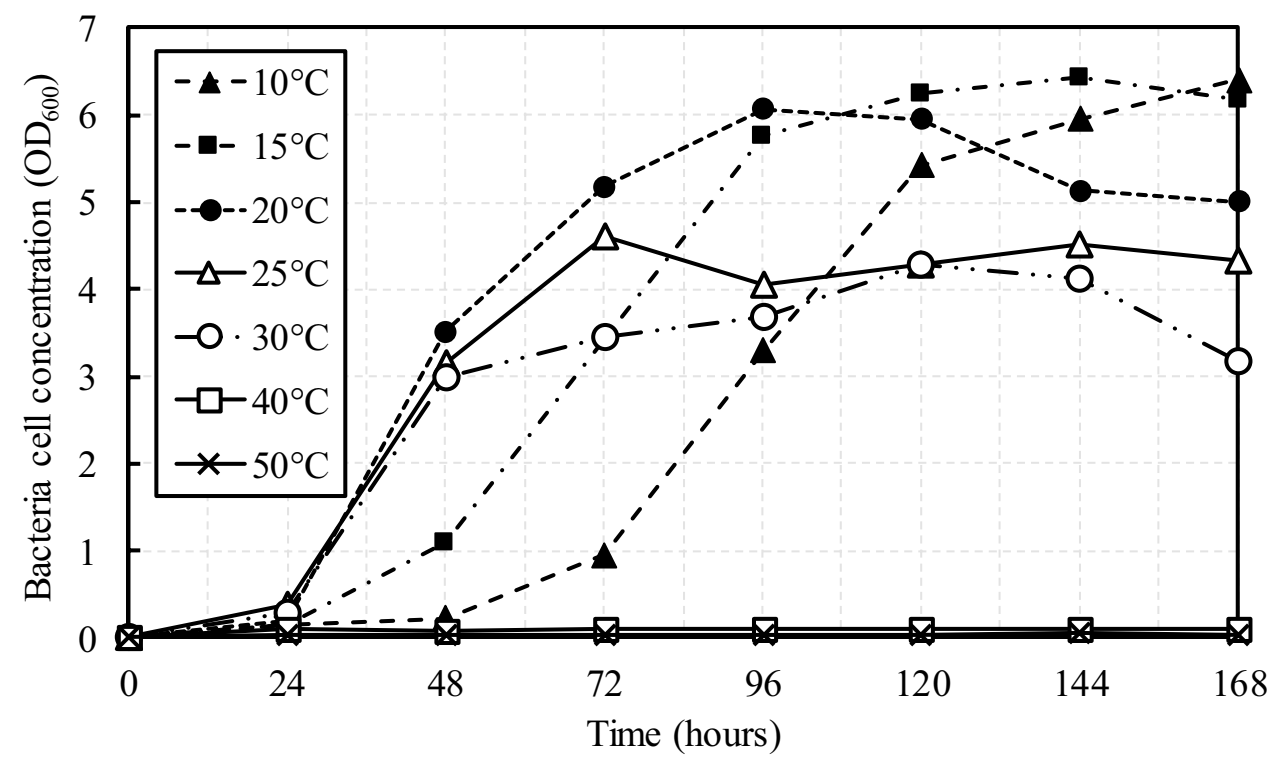

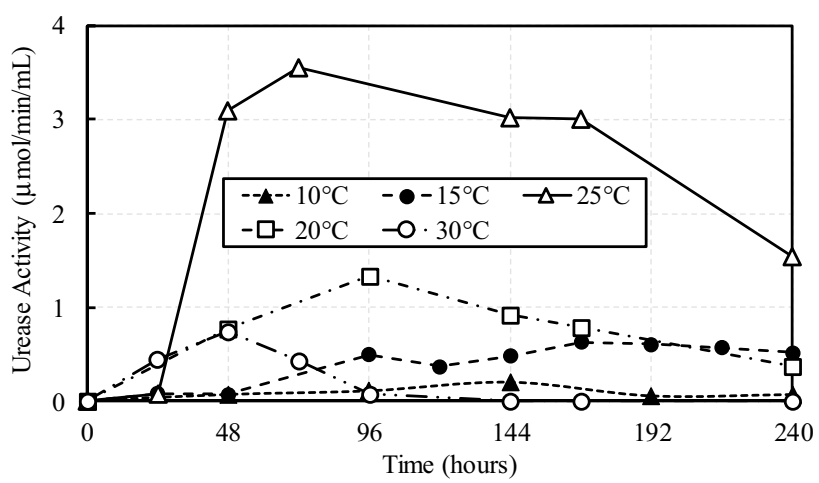

Fig. 7 Stability of the urease enzyme with the time at different cultivation temperatures

temperature range $20-25^{\circ} \mathrm{C}$ (ranged between 1.5 and 3 $\mu \mathrm{mol} / \mathrm{min} / \mathrm{mL}$ ). The urease activity reached the optimum value at $25^{\circ} \mathrm{C}(3 \mu \mathrm{mol} / \mathrm{min} / \mathrm{mL})$, above which the activity dropped significantly and became negligible. The urease activities of the bacteria at $15^{\circ} \mathrm{C}$ and $10^{\circ} \mathrm{C}$ are $0.75 \mu \mathrm{mol} /$ $\mathrm{min} / \mathrm{mL}$ and $0.2 \mu \mathrm{mol} / \mathrm{min} / \mathrm{mL}$ respectively, and below $5{ }^{\circ} \mathrm{C}$, the activity becomes insignificant.

The long-term stability of bacterial urease is very essential for the adequate carbonation during treatment period under the minimal supply of bacteria cells. Urease is a molecule composed of protein subunits, that could be typically broken down into amino acids by cellular enzyme called protease (proteolysis) $[40,41]$. The stability of bacterial urease with the time is shown in Fig. 7. The results indicate that the urease activity of Lysinibacillus xylanilyticus remains relatively stable within $15-25^{\circ} \mathrm{C}$ against proteolysis. However, the urease activity became negligible within the short period at higher temperature 
$\left(30^{\circ} \mathrm{C}\right)$, suggesting that the bonds between protein subunits weaken at higher temperature and tended to break down quickly.

\subsubsection{Effect of $\mathrm{pH}$ in urease performance}

Effect of $\mathrm{pH}$ conditions in urease activity of Lysinibacillus xylanilyticus is illustrated in Fig. 8 . The results show that the highest urease activity was found to be within the $\mathrm{pH}$ range from 7 to 8 (weak alkali conditions). Relatively lower urease activity was found under acidic (less than $\mathrm{pH} 6$ ) and alkali (at pH 9) conditions, as bacterial urease underwent significant denaturing in severe acidic and alkali conditions.

\subsubsection{Enzyme location}

The whole cell culture medium was centrifuged $(8000 \mathrm{rpm}$, $10{ }^{\circ} \mathrm{C}, 5 \mathrm{~min}$ ) to separate the cell pellets from the culture supernatant. The separated cell pellets were washed and resuspended into same volume of autoclaved distilled water, followed by urease activity test was performed separately on cell medium (cells + distilled water) and supernatant. The urease activity of cell medium was very close to that of whole cell culture medium, and a negligible activity was observed in supernatant. The results suggest that the urease enzyme of Lysinibacillus xylanilyticus is not segregated into extracellular medium but localized completely in or on the cell membrane, indicating urease of Lysinibacillus xylanilyticus is cytoplasmic enzyme. This is similar to that reported to most of the urease of the

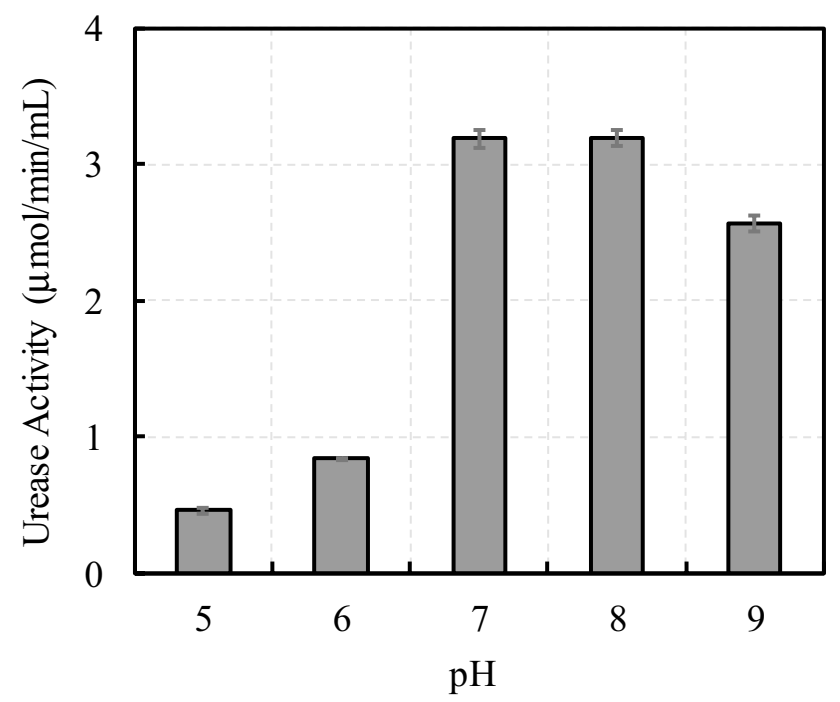

Fig. 8 Effect of $\mathrm{pH}$ condition of reaction medium on urease performance. The error bars represent the mean $\pm S D(n=3)$ species including Sporosarcina and Pararhodobacter sp. $[27,41]$.

\subsubsection{Discussion}

Numerous investigators have studied the effect of temperature on the rate of urea hydrolysis of many soil bacteria $[23,27,30,40]$. In general, their results have indicated that the rate of urea hydrolysis increases with increasing temperature, suggesting that the urease of most of the soil bacteria is not heat inactivated (up to the temperature ranging $45-60^{\circ} \mathrm{C}$ ). For an example, urease activity of Sporosarcina Pasteurii increased proportionally with temperature between $25^{\circ} \mathrm{C}$ and $60^{\circ} \mathrm{C}$ [24]. The similar tendency is reported for Pararhodobacter sp. [27], Deleya venusta [42] and Strep-tococcus salivarius [43]. It is worth to note that the Lysinibacillus xylanilyticus reported herein exhibited a distinct behavior regarding urease activity, in which the urease enzyme is highly heat inactivated; urease is not stable even at $30^{\circ} \mathrm{C}$. On the other hand, the urease enzyme is more stable and consistently performs for long period at lower temperatures below $30^{\circ} \mathrm{C}$ (Fig. 7). Theoretically, the activation energy for a specific enzyme-catalyzed reaction is constant [30]. Since the mean activation energy of most of the bacterial urease is high, bacteria could effectively catalyst the hydrolysis of urea at high temperatures (above $30^{\circ} \mathrm{C}$ ), resulting negligible urease potential at lower temperatures. Since the Lysinibacillus xylanilyticus was isolated from subarctic cold region, it exhibited high urease potential at temperatures below $30^{\circ} \mathrm{C}$, suggesting low energy requirement for enzyme-catalyzed reaction. However, urease activity of the bacteria becomes negligible below $5{ }^{\circ} \mathrm{C}$, suggesting that the supply energy below $5^{\circ} \mathrm{C}$ is deficient to activate the enzyme catalyzation. Therefore, application of the species reported herein is limited at the temperatures close to or below the freezing point of water.

Different soil bacteria has different tolerance towards $\mathrm{pH}$ conditions. Some ureolytic bacteria including Bacillus cereus show higher activity at around $\mathrm{pH} 4$ compared to the neutral $\mathrm{pH}$ conditions suggesting acidic urease compatibility [44]. Also, the bacteria (for example Helicobacter pylori) living in harsh acidic environment produce more urease enzyme at acidic conditions [45]. In fact, urease activity of those bacteria is related to their stress response to survive at acidic condition, wherein hydrolysis of urea would neutralize the acidic environment leading to the bacterial survival. On the other hand, urease enzyme of some bacteria tends to be more active in neutral to alkaline environmental conditions. Lysinibacillus xylanilyticus reported in this paper showed the highest activity at weak alkali conditions. Similar phenomena could be seen on certain microbial urease like Sporosarcina pasteurii 
[23, 40], Pararhodobacter sp. [27] and Klebsiella aerogenes [44], those have the optimum activity under weak alkaline conditions.

\subsection{Soil column test}

\subsubsection{Behavior of uniformly graded sands}

The effect of MICP in slope soil was examined by comparing the behavior of three uniformly graded sands with different particle sizes. All the columns specimens were treated exactly under same physical $\left(25^{\circ} \mathrm{C}\right)$ and chemical conditions (14 cementation injections; 2 bacterial injections) by surface percolation as explained in previous section. The entire column of all type of soils were successfully cemented, and the cemented profiles are presented in Fig. 9. Figure 10 presents the UCS of the different soils with respect to the depth. The results indicate that the UCS values increase with the decrease in particle size in the uniformly graded sands. The average UCS estimated close to the surface of Mizunami, Mikawa and Toyoura sands $\left(D_{50}\right.$ of $1.6 \mathrm{~mm}, 0.87 \mathrm{~mm}$ and $\left.0.2 \mathrm{~mm}\right)$ are $1.82 \mathrm{MPa}$, $2.67 \mathrm{MPa}$ and $3.98 \mathrm{MPa}$ respectively. The UCS values and the calcium carbonate content (Fig. 11) of coarse and find sands reported herein are in a good agreement with the results reported by Cheng and Cord-Ruwisch [3]. Basically, coarse sands have high permeability that leads to the high liquid infiltration compared to the fine sands. The calcium ion concentrations of the drainage measured during the treatment (Fig. 12) suggest that more than $80 \%$ of the unreacted cementation solutions have reached the bottom

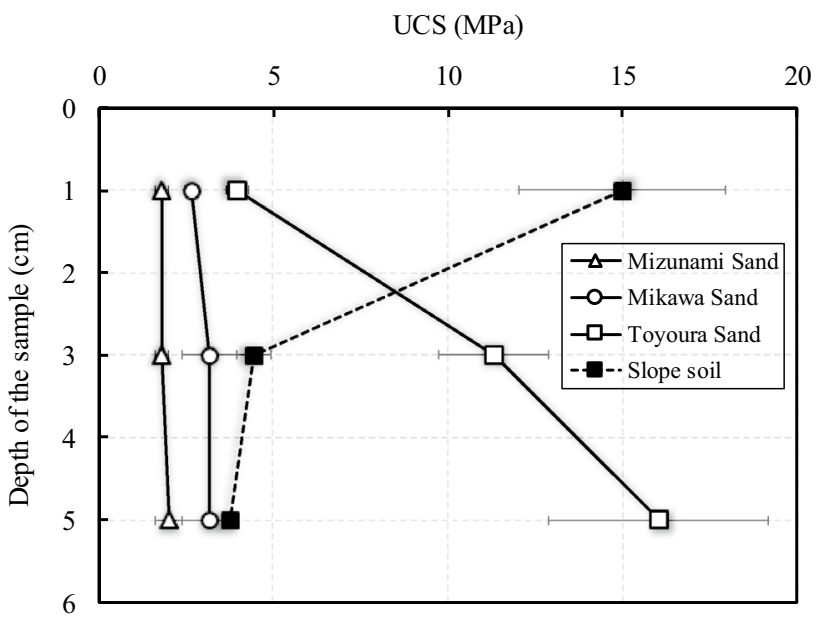

Fig. 10 UCS profiles of cemented soil columns. The error bars represent the mean $\pm S D(n=3)$

in the coarse sand columns (Mizunami and Mikawa) due to the high infiltration rate facilitated by the large pore spaces.

The UCS of all the uniformly graded sands increases with the depth of the sample. In coarse sand columns, the UCS and $\mathrm{CaCO}_{3}$ content are relatively constant from the surface to the middle and then slightly increase with the depth. A similar observation in coarse sand has been reported by Cheng and Cord-Ruwisch [3]. In contrast, fine sand exhibits significant improvement in UCS with the depth, which could be due to the increased capillary effect along the sample depth. The higher capillary forces in fine

Fig. 9 Cemented columns of a Mizunami sand, b Mikawa sand, c Toyoura sand and $\mathbf{d}$ slope soil

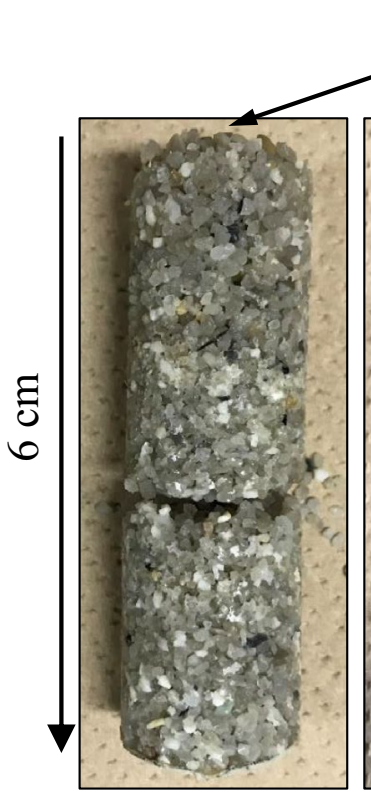

(a)

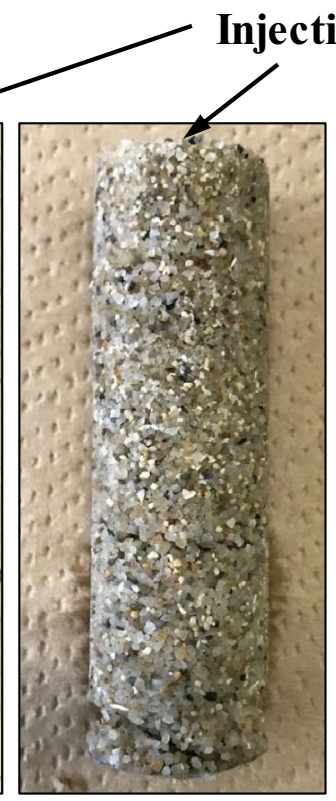

(b)

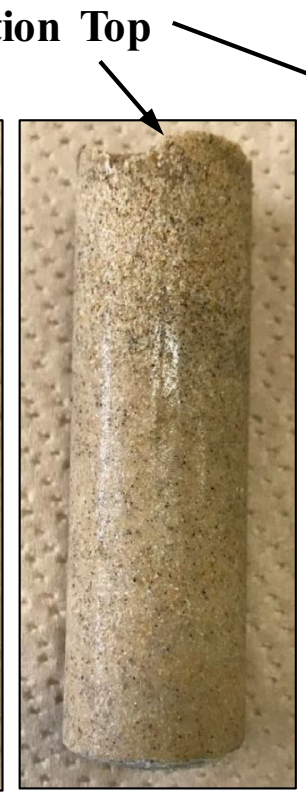

(c)

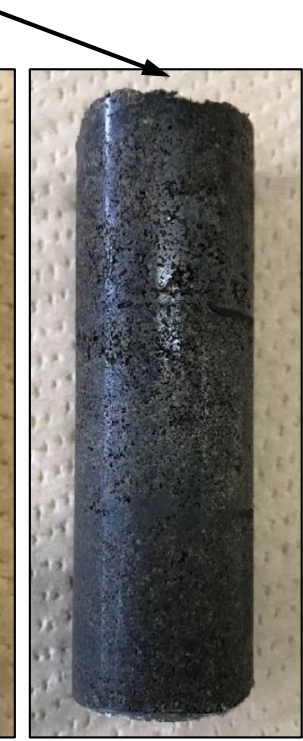

(d) 


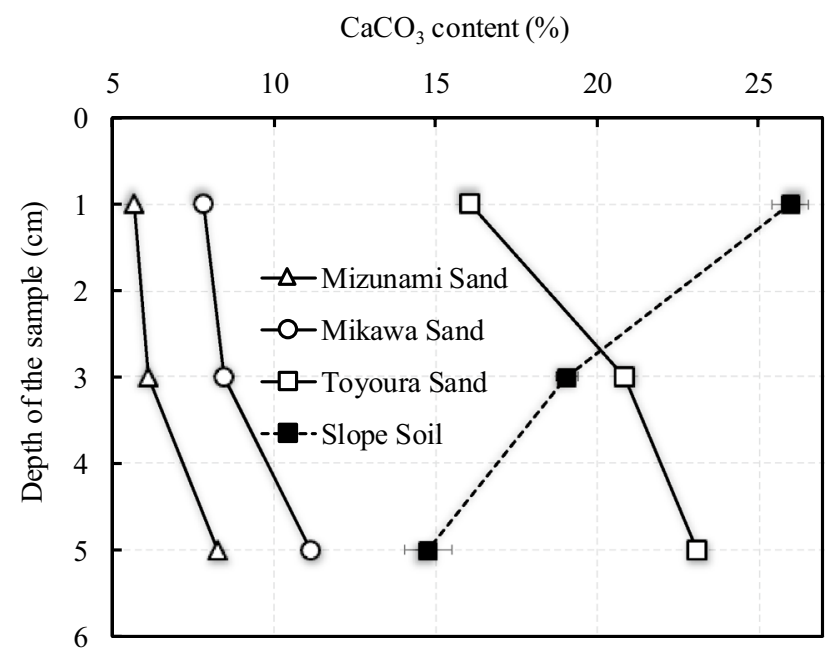

Fig. 11 Calcium carbonate content profiles of cemented soil columns. The error bars represent the mean $\pm S D(n=3)$

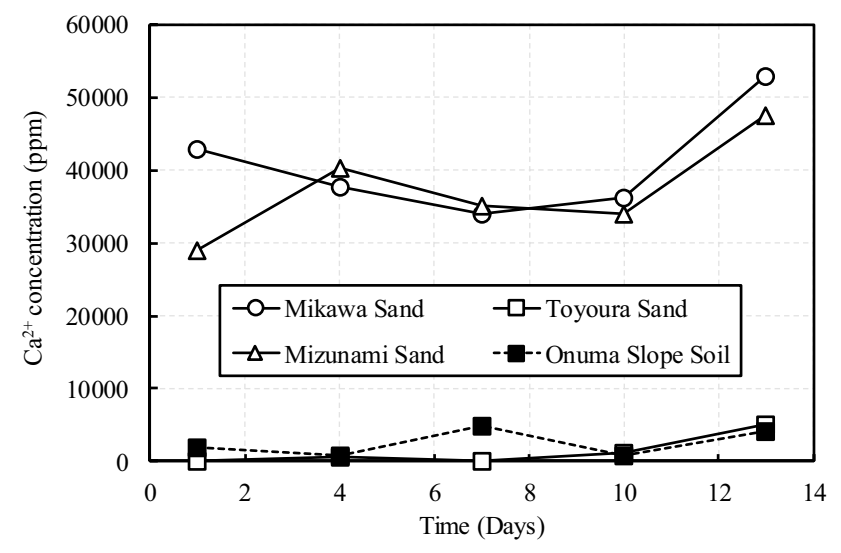

Fig. $12 \mathrm{Ca}^{2+}$ concentration measured at outlet drainage of column specimens during the treatment

sand tended to retain certain amount of cementation solutions close to particle contacts, resulting higher deposition of calcium carbonate and exhibiting higher UCS at the bottom sample compared to that at top.

\subsubsection{Behavior of slope soil}

The slope soil showed a distinct behavior compared to the behaviors of uniformly graded sands. The average particle size of Toyoura sand and slope soil are relatively similar $(0.20 \mathrm{~mm}$ and $0.23 \mathrm{~mm}$ respectively). Also, both soils exhibited that around $80-90 \%$ of the calcium ions in cementation solution have been already utilized by the time it reached the bottom (Fig. 12). However, treated soils exhibited a significant difference regarding their UCS (Fig. 10) and $\mathrm{CaCO}_{3}$ content (Fig. 11). The UCS of the slope soil estimated close to the surface is $14.98 \mathrm{kPa}$, which is around 3.75 times higher than the UCS of cemented Toyoura sand. There was no difference in the treatment process for the above specimens; therefore, the reason for the remarkable UCS achieved in slope soil could be due to its grain size distribution. Slope soil is a well graded sand consisting very fine sand content of $12 \%$, leading to effective packing and cementation in the matrix. It was also observed that the infiltration rate of cementation solution decreased with the number of injections, which would be the result of the reduction in permeability due to the cementation at pore spaces.

In contrast to the UCS and $\mathrm{CaCO}_{3}$ profile of uniformly graded sand columns, the UCS and carbonate content of slope soil decrease with the depth (Figs. 10 and 11). The higher cementation at the top of the column specimen is presumed to be due to the biological filtration. The bacteria were applied into specimen from top and allowed to flow through the soil. As the bacteria travel through smaller pore space of the slope soil, they might be filtered through the soil with a reduction of bacteria concentration along the path. Therefore, a larger concentration of bacteria cells would retain at the top of the column compared to the bottom. The distribution of carbonate cementation observed in slope soil was similar to those reported by Cheng and Cord-Ruwisch [3], Feng and Montoya [11] and Martinez et al. [46]. Furthermore, a very less bacterial turbidity was detected at the outlet of slope soil column, suggesting that most of the cells are immobilized in the soil matrix by the filtration. It has been reported that the cementation profiles are generally determined by the bacteria distribution in the specimen [46]. The uniformity of the precipitated calcium carbonate along the soil specimens is further discussed in the subsequent section.

\subsubsection{Microscale properties of MICP treated soils}

The precipitation characteristics of MICP treated soils were investigated in microscale using SEM (Scanning electron microscopy). All the representative samples used for the SEM observation were obtained from $1 \mathrm{~cm}$ depth of the treated columns. The SEM images of uniformly graded sands are shown in Fig. 13. The images of MICP treated sands show calcium carbonate precipitated at particle contacts (contact cementing) and slightly coating particle surfaces. As the particle size of sand reduces from $1.6 \mathrm{~mm}$ to $0.2 \mathrm{~mm}$, the images of the MICP treated sands show an increase in precipitated carbonate content (consistent with the carbonate content measurement of sands presented in Fig. 11).

The number of particles contact highly influences the effectiveness of MICP. Generally, bacteria cells prefer to position themselves in smaller surface features (such as 


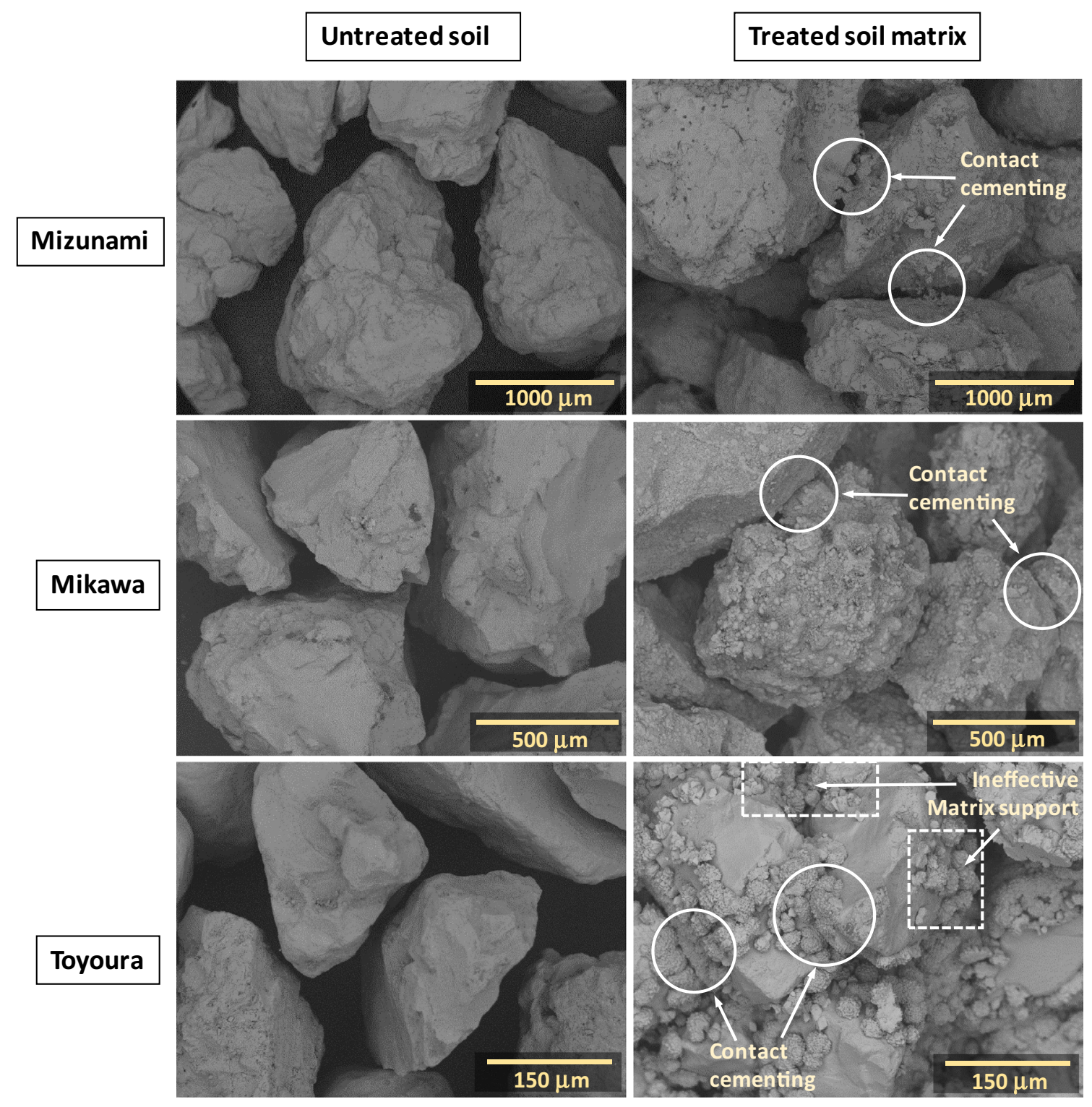

Fig. 13 Scanning electron microscopy images of uniformly graded sands (Mizunami, Mikawa and Toyoura sands)

near particle-particle contacts) compared to the particle surface, which is due to the reduced shear and a higher availability of nutrients at the particle contacts [4]. Therefore, the calcium carbonate cement preferentially precipitates at the particle contacts while coating the soil grains during the treatment. Due to the higher number of particle contacts in fine Toyoura sand, the rate of calcium carbonate precipitation was higher compared to that in coarse sands (Fig. 13). It should be noted that the matrix supporting is enabled by filling the void space with or without contacting the soil particles (i.e. grow from particle surface into pore space to create bridges between particles), when the soils are treated in saturated conditions $[4,5,11]$. Well coated grains with matrix supporting by calcite crystals are also often observed by many researchers in medium to coarse sands treated under saturated conditions $[2,5$, $11,47]$. It is worth noting that the microstructure reported herein for the specimens treated under percolation condition slightly differ from that reported for saturated conditions. Since the surface percolations method is achieved with the aid of gravitational and capillary forces, contribution of matrix supporting is limited. The growth of the crystals from the particle surface into void space is not observed in uniformly graded sands treated by surface percolation (Fig. 13).

Figure 14 presents the SEM image of MICP treated slope soil (Fig. 14a shows the untreated soil). Based on the shape of the $\mathrm{CaCO}_{3}$ crystal, the precipitated morphology 

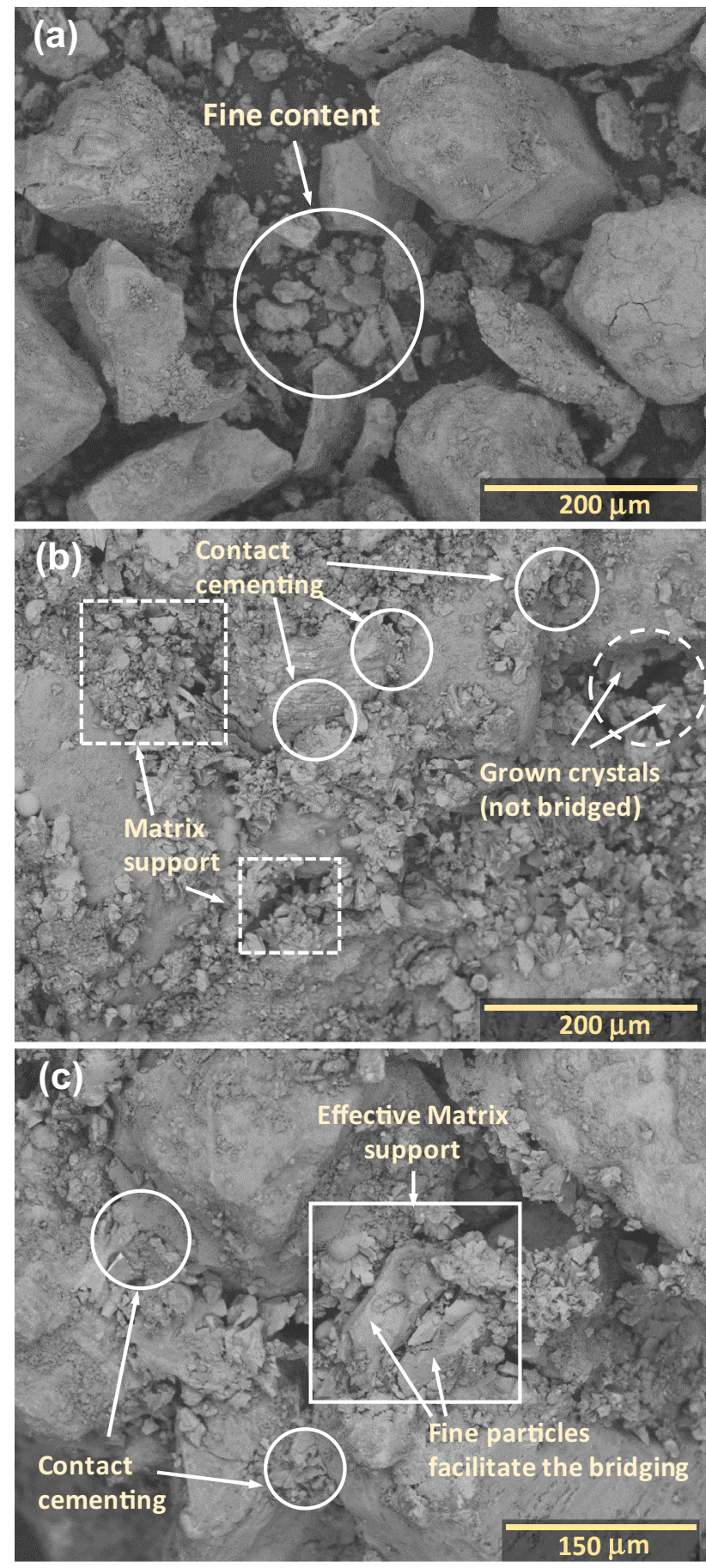

Fig. 14 Scanning electron micrographs of a untreated slope soil, $\mathbf{b}$ treated slope soil matrix and c effective matrix support by fine particles slope soil

in slope soil would be calcite (typical rhombohedral crystals). It can be clearly seen that the sand particles ranging from coarse to fine form an effective matrix in slope soil for the MICP (Fig. 14b). It is also worth noting that presence of fine particles could change the microstructure of sand skeleton and govern the behavior significantly.

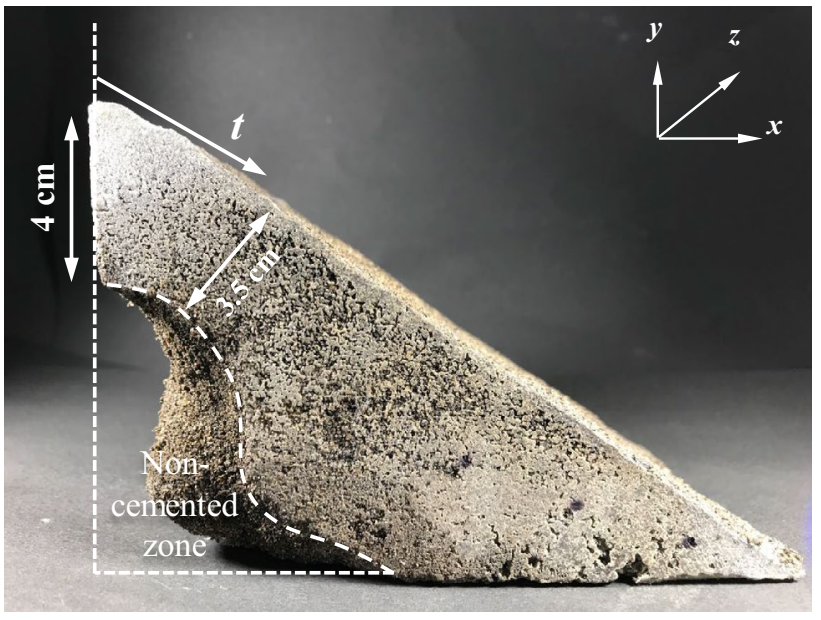

Fig. 15 Profile of the cemented slope model

Most of the sand particles are in contact with some of the fine particles between them, and the rest filled the void spaces (Fig. 14b). Also, some of the fine particles are cemented both to each other and to the sand particles (Fig. 14c). The presence of fine content (12\%) in slope soil significantly increases the number of particle contacts by bonding with the sand grains. It can be observed that the fine content plays a very important role in matrix supporting by enabling intermediate supports to form bridges among the carbonate crystals that have grown in void spaces (Fig. 14c), thus, strengthening the force chain of the treated matrix. It should also be stated here that the MICP in very fine soils are limited due to the limited rate of permeability that generally takes very longer time to infiltrate the reactants [13], and free passage of the bacteria might be inhibited due to the small pore throat size of fine soils [47].

\subsection{Slope model solidification test}

Slope model test is the scale-up version of soil column tests. Because the small columns are limited by confinement and boundary effects, the model test was additionally performed to demonstrate the feasibility of slope soil stabilization. After the 14 days of treatment, the slope was flushed with about $5 \mathrm{~L}$ of tap water to remove all soluble salts, followed by, slope specimen was carefully removed from the mold and submerged into the water bath to eliminate the uncemented aggregates. The cemented profile is presented in Fig. 15. The observation indicates that more than $80 \%$ of the soil was successfully cemented, and a stiff layer of around $3-4 \mathrm{~cm}$ along the entire surface was achieved. However, cementation was not observed within the zone below the top slope (Fig. 15), remained as untreated soil. The surface UCS was used as the indicator 
to evaluate the improvement of slope, besides the UCS estimated by the needle penetration tests are illustrated in Fig. 16. The results show that the bio-cemented slope surface had considerable UCS between 2 and $8 \mathrm{MPa}$, and relatively lower UCS values were obtained below the surface of the slope.

\subsubsection{Uniformity of cementation}

It is highly necessary to study uniformity of precipitated calcium carbonate along laterally ( $t-z$ axis) and vertically $(x-y$ axis) in slope, as the MICP in soils is achieved by biochemical injections. Before the measurements, it was anticipated that relatively a homogeneous cementation could be attained along the surface $(t-z)$ by the injection method. However, Fig. 16 suggests that the surface UCS increases along the distance $(t)$ measured from the top slope, and the highest surface UCS was obtained near bottom slope. The average UCS at the bottom slope was about $7 \mathrm{MPa}$, whereas that of top is only $2 \mathrm{MPa}$. This variation along the surface could be attributed to the localization of bacteria cells. The consecutive injections of cementation solution (every 24 h) i.e. propagated flow-lines would possibly transport the bacteria cells towards downslope, results increase in cell concentration in the direction of downslope; thus, more or less of the bacteria cells will in turn increase or decrease the cementation and UCS. The Precipitated carbonate profile is not uniform along the slope depth $(x-y)$ similar to that observed in column specimens, suggesting higher calcium carbonate content near to the injection port.
The spatial distribution of calcium carbonate generally follows the trend of microbe distributions along the specimen length/depth [46]. As previously discussed, higher concentration of bacteria cells was filtered at the top zone, leading to higher deposition of carbonate content near the injection surface. In order to confirm this postulation, soil samples were collected from three depths of slope after performing the biological injection, and the number of existing bacteria cells were measured by similar method used for isolation of bacteria. The measured locations are indicated clearly in Fig. 3. The results (Fig. 17) suggest that the distribution of bacteria

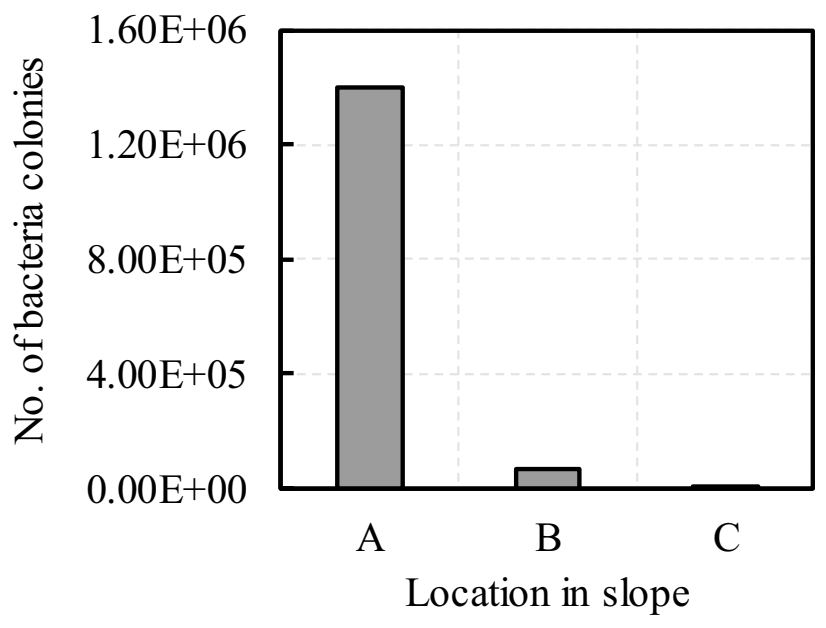

Fig. 17 Distribution of bacteria cells along the depth of the slope (locations A, B and C are indicated in Fig. 3)
Fig. 16 UCS profile along the surface ( $t-z$ axis) of the treated slope (measured by needle penetrometer)

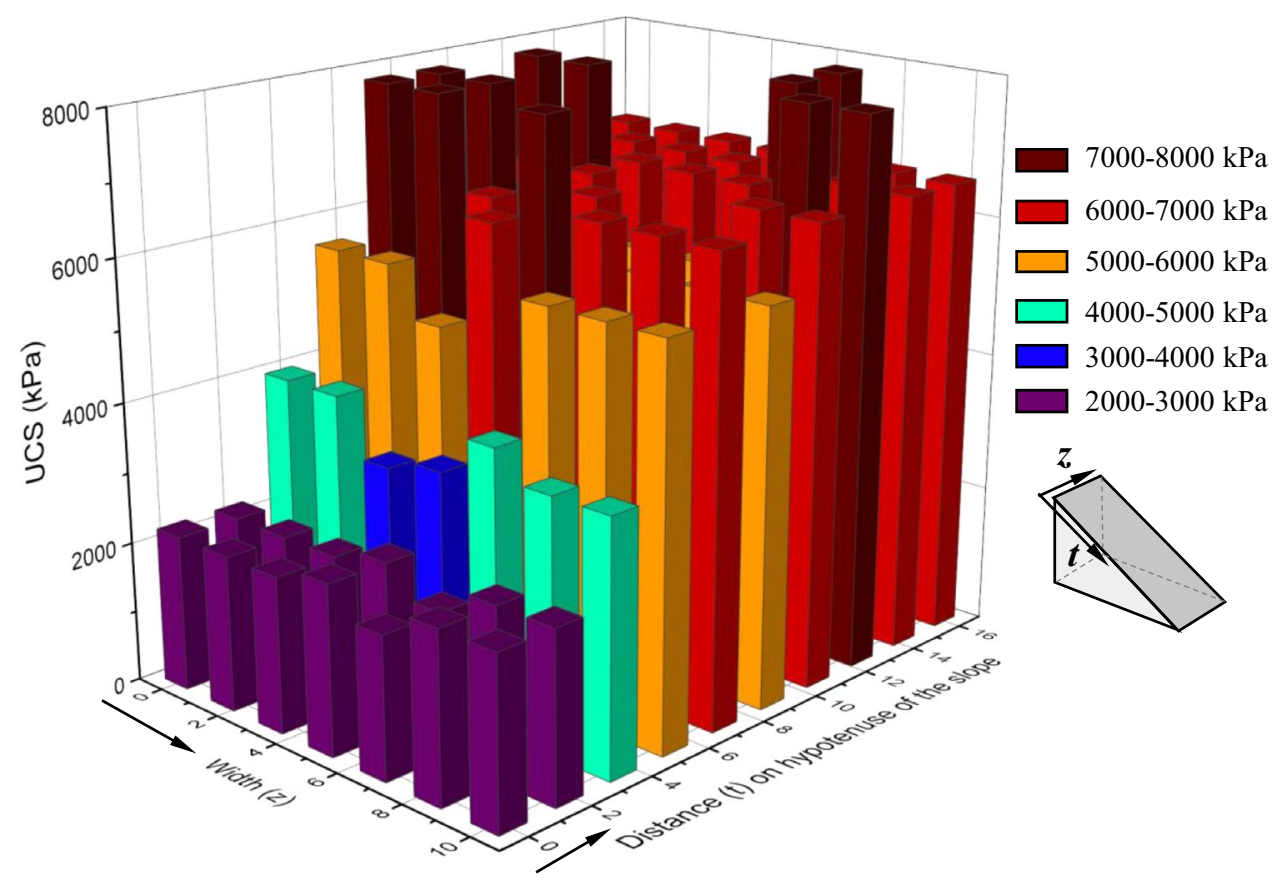


in slope soil drastically decreases with the depth of slope i.e. the number of cells per unit gram soil at $1 \mathrm{~cm}$ below the slope surface and at the bottom slope are $1.4 \times 10^{6}$ and $5 \times 10^{3}$ respectively. Thus, it has been confirmed that most of the bacteria cells were filtered in surface zone, resulting high cementation at the surface zone.

In addition, surface zone closest to the injection port is generally in exposure to higher concentrated reactants than the bottom zone [1]; therefore, higher carbonate content was precipitated at surface zone. It also has been reported that the amount of urease, precipitation rate and nutrient concentrations also have a great influence in carbonate distribution and must be maintained at their minimum to achieve a homogeneous cementation along the soil columns $[13,47]$.

The measurements indicate that the slope soil consists of very small amount $(0.22-0.25 \%)$ natural carbonate content. As reported by Mortensen et al. [13], the soil particles consisted of carbonate content could provide ideal surfaces and nucleation sites for the additional precipitation of carbonate crystals. At the same time, the residual soil would consist of soil particles in broad range of shapes, irregularities and with varying surface roughness, which could provide additional effects in precipitation of carbonate. Future works should clearly address the effect of particle shapes and surface roughness to improve the understanding on the behavior of residual soils.

The threshold calcium carbonate content required to provide measurable UCS of slope soil was found to be around 3\%. The carbonate content reported herein is in a good agreement with the minimum carbonate content (3.5\%, for the sand with $D_{50}$ of $165 \mu \mathrm{m}$ ) reported by Whiffin et al. [1]. Soil cemented below the threshold carbonate content exhibited an unsolidified loose matrix which was similar to the untreated soil. However, small carbonate crystals on the particle surface were evidenced through SEM analysis. At the same time, Feng and Montoya [11] and Lin et al. [5] have reported that the minimum carbonate content required to increase the strength of sands ( $D_{50}$ of $0.22 \mathrm{~mm}$ and $0.33 \mathrm{~mm}$ respectively) was around $1 \%$. Actually, the threshold carbonate content of a soil is related to the number of particle contacts and grain size. Due to the increased number of particle contacts in slope soil, relatively a higher amount of threshold carbonate content (3\%) (compared to that reported by Feng and Montoya [11] and Lin et al. [5]) was required to provide the measurable strength.

Figure 18 presents a compilation of all UCS results obtained versus the measured calcium carbonate content. The UCS increases during MICP improvement as calcium carbonate precipitates and cements the soil particles, as a result of void space reduction. It is also clear that the UCS increases exponentially with the increase in calcium

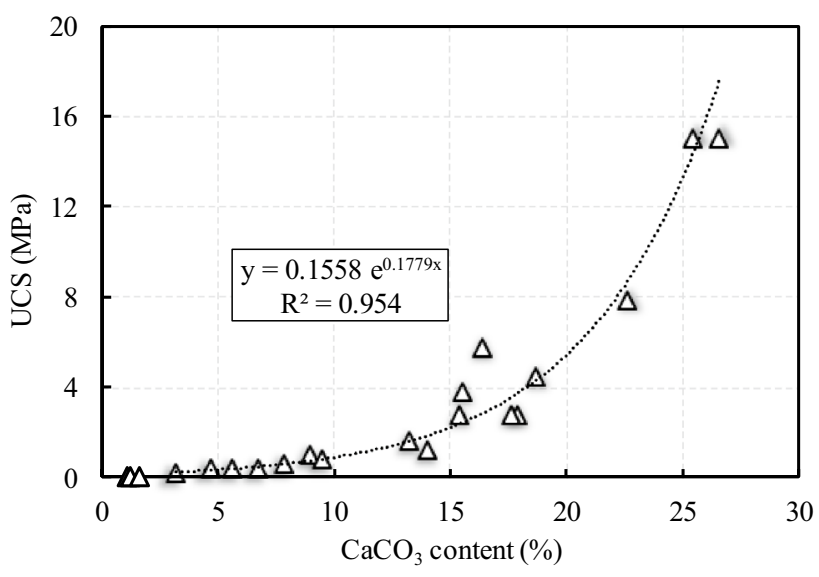

Fig. 18 Relationship between UCS verses calcium carbonate content in slope soil

carbonate content, similar to that reported in previous studies $[2,6,32]$.

\subsubsection{Field implication and associated limitations}

To date, most of the studies of MICP have been extensively investigated under saturated or water-logged environmental conditions $[1,5,6,10,47]$, in which bacterial and cementation medias were injected to the specimen by a saturated flow with a constant flow rate using peristaltic pump. Pumping method has often resulted a heterogeneously cemented profile in soil columns, suggesting a higher precipitation level at the influent column. Recently, Li et al. [48] have proposed a rotating soak method to promote the uniformity of cementation in specimen by facilitating more nutrition supply and air replenishment within the soil for effective bacterial performance. However, in the real field, it would be a challenge to maintain the saturated or submerged flow conditions during the treatment period, which requires hydraulic injection of cementation/ biological solutions, extraction of effluent solution and heavy machinery systems. Therefore, it is an essential to introduce alternative MICP approaches to produce carbonate cement with high efficacy with desirable cost minimization. The simple surface percolation technique demonstrated in this study is more suitable for field application, which eliminates the destruction of existing soil structure and reduces the costs of required labour and machinery. However, it would be more effective, if the surface percolation is promoted to spraying instead of injections, which is left for the future work to be performed in the subsequent phase of this study.

In civil engineering applications such as slope surface stabilizations, it is highly important to immobilize the ureolytic bacteria within the target surface zones, so that 
sufficient carbonate can be precipitated throughout the required zone. The experimental observations discussed in this paper suggest well immobilization of bacteria only within the surface zone, and the particle size distribution of slope soil limits the distribution of bacteria to more deeper depths. Therefore, it is appropriate to recommend the technique for slope surface stabilization i.e. stabilizing the slope by enhancing the surface cover condition of the slope and promoting high aggregate stability at the surface zone, which could be enabled against surface erosion. The results also indicate, treating the soil by surface percolation method could strengthen the soil significantly by forming more effective crystals at free-draining environmental conditions and can be highly applicable on unsaturated or partially saturated natural slopes and embankments.

In the injection method investigated herein, grain size distribution highly governs the efficiency of MICP. Fine sands, well graded soils and soils consisting of certain amount of fine particles have less permeability (compared to the coarse soils) leading to low infiltration rate, that often increases the risk regarding local clogging. In order to avoid the risk of clogging, Whiffin et al. [1] have suggested a faster injection/flow rates of reactants by allowing less reaction time along the path. Afterwards, Cheng and Cord-Ruwisch [3] have reported the observation of non-clogged fine and coarse sand columns treated under higher infiltration rates $(7-28.5 \mathrm{~cm} / \mathrm{min})$. They have also reported that severe clogging occurred in fine sand when it was treated under low infiltration rate less than $0.25 \mathrm{~cm} /$ $\mathrm{min}$. Therefore, a moderate infiltration rate of $2-4 \mathrm{~mL} / \mathrm{min}$ was maintained during the treatment period (no clogging occurred during the treatment).

\section{Conclusions}

The findings indicate that the bacteria (Lysinibacillus xylanilyticus) isolated from the subarctic cold region have a significant potential to produce urease enzyme at temperatures $15-25^{\circ} \mathrm{C}$, suggesting low-temperature urease compatibility. On the other hand, the growth and the urease production of the bacteria is limited at the temperatures above $30^{\circ} \mathrm{C}$. In the neutral-weak alkaline environmental conditions, urease is more stable and consistently performs. It is also found that the urease is not segregated into the extracellular medium indicating that bacterial urease is a cytoplasmic enzyme. On the whole, the novel isolate exhibits a significant impact for MICP applications in subarctic cold climatic regions.

The effect of carbonate precipitation on the process of strengthening in slope soil was investigated by comparing the behaviour of three uniformly graded sands.
Microstructure of the soils treated by surface percolation shows the formation of effective crystals at particle contacts. Presence of fine content governs the behavior of residual slope soil significantly. It increases the number of particle contacts by bonding with the sand grains and participates in the force chain of the treated matrix. The fine content provides the matrix support effectively by facilitating intermediate supports to form bridges between carbonate crystals. However, grain size distribution tends to filter more bacteria at surface zone of slope, results high cementation at the surface level and relatively a long linear reduction in carbonate precipitation along the profile is observed. This preliminary investigation suggests that the technique can be implemented for stabilizing the slope by enhancing the cover condition of the slope, and the results obtained from this investigation would be highly beneficial to promote the study to the large scale.

Acknowledgements The authors highly appreciate the Hokkaido Office, East Nippon Expressway Company Limited, Sapporo, Hokkaido, Japan for providing the research opportunity and the continuous supports in sample collection.

\section{Compliance with ethical standards}

Conflict of interest All the authors declare no conflict of interest.

\section{References}

1. Whiffin VS, van Paassen LA, Harkes MP (2007) Microbial carbonate precipitation as a soil improvement technique. Geomicrobiol J 24:417-423. https://doi.org/10.1080/01490450701436505

2. Amarakoon GGNN, Kawasaki S (2018) Factors affecting sand solidification using MICP with Pararhodobacter sp. Mater Trans 59:72-81. https://doi.org/10.2320/matertrans.M-M2017849

3. Cheng L, Cord-Ruwisch R (2014) Upscaling effects of soil improvement by microbially induced calcite precipitation by surface percolation. Geomicrobiol J 31:396-406. https://doi. org/10.1080/01490451.2013.836579

4. DeJong JT, Mortensen BM, Martinez BC, Nelson DC (2010) Biomediated soil improvement. Ecol Eng 36:197-210. https://doi. org/10.1016/j.ecoleng.2008.12.029

5. Lin H, Suleiman MT, Brown DG, Kavazanjian E (2016) Mechanical behavior of sands treated by microbially induced carbonate precipitation. J Geotech Geoenviron Eng 142:04015066-1-13. https://doi.org/10.1061/(ASCE)GT.1943-5606.0001383

6. van Paassen LA, Ghose R, van der Linden TJM et al (2010) Quantifying biomediated ground improvement by ureolysis: large-scale biogrout experiment. J Geotech Geoenviron Eng 136:1721-1728. https://doi.org/10.1061/(ASCE)GT.19435606.0000382

7. Montoya BM, DeJong JT, Boulanger RW (2013) Dynamic response of liquefiable sand improved by microbial-induced calcite precipitation. Géotechnique 63:302-312. https://doi. org/10.1680/geot.sip13.p.019

8. Gomez MG, Anderson CM, Graddy CMR et al (2017) Largescale comparison of bioaugmentation and biostimulation approaches for biocementation of sands. J Geotech Geoenviron 
Eng 143:04016124. https://doi.org/10.1061/(ASCE)GT.19435606.0001640

9. Danjo T, Kawasaki S (2016) Microbially induced sand cementation method using Pararhodobacter sp. Strain SO1, inspired by Beachrock formation mechanism. Mater Trans 57:428-437. https ://doi.org/10.2320/matertrans.M-M2015842

10. Feng K, Montoya BM (2017) Quantifying level of microbialinduced cementation for cyclically loaded sand. J Geotech Geoenviron Eng 143:06017005. https://doi.org/10.1061/(ASCE) GT.1943-5606.0001682

11. Feng K, Montoya BM (2016) Influence of confinement and cementation level on the behavior of microbial-induced calcite precipitated sands under monotonic drained loading. J Geotech Geoenviron Eng 142:04015057. https://doi.org/10.1061/(ASCE) GT.1943-5606.0001379

12. van Paassen LA (2011) Bio-Mediated Ground Improvement: From Laboratory Experiment to Pilot Applications. Geo-frontiers 2011. American Society of Civil Engineers, Reston, pp 4099-4108

13. Mortensen BM, Haber MJ, Dejong JT et al (2011) Effects of environmental factors on microbial induced calcium carbonate precipitation. J Appl Microbiol 111:338-349. https://doi.org/10.111 1/j.1365-2672.2011.05065.x

14. Soon NW, Lee LM, Khun TC, Ling HS (2014) Factors affecting improvement in engineering properties of residual soil through microbial-induced calcite precipitation. J Geotech Geoenviron Eng 140:04014006. https://doi.org/10.1061/(ASCE)GT.19435606.0001089

15. Osinubi KJ, Eberemu AO, Gadzama EW, ljimdiya TS (2019) Plasticity characteristics of lateritic soil treated with Sporosarcina pasteurii in microbial-induced calcite precipitation application. SN Appl Sci 1:829. https://doi.org/10.1007/s42452-019-0868-7

16. Li C, Yao D, Liu S et al (2018) Improvement of geomechanical properties of bio-remediated Aeolian sand. Geomicrobiol J 35:132-140. https://doi.org/10.1080/01490451.2017.1338798

17. Fujita Y, Grant Ferris F, Daniel Lawson R et al (2000) Calcium carbonate precipitation by ureolytic subsurface bacteria. Geomicrobiol J 17:305-318. https://doi.org/10.1080/782198884

18. Gomez MG, Martinez BC, DeJong JT et al (2015) Field-scale bio-cementation tests to improve sands. Proc Inst Civ Eng - Gr Improv 168:206-216. https://doi.org/10.1680/grim.13.00052

19. Gat D, Ronen Z, Tsesarsky M (2016) Soil bacteria population dynamics following stimulation for ureolytic microbial-induced $\mathrm{CaCO}_{3}$ precipitation. Environ Sci Technol 50:616-624. https:// doi.org/10.1021/acs.est.5b04033

20. Sensoy T, Bozbeyoglu NN, Dogan NM, et al (2017) Characterization of calcium carbonate produced by ureolytic bacteria (Sporocarcina pasteurii ATCC 6453 and Bacillus aerius U2) and effect of environmental conditions on production of calcium carbonate. In: 15th International conference on environmental science and technology. Rhodes, Greece

21. DeJong JT, Martinez BC, Mortensen BM, et al (2009) Upscaling of bio-mediated soil improvement upscaling of bio-mediated soil improvement. In: 17th International conference on soil mechanics and geotechnical engineering. Netherlands, pp 2300-2303

22. Yang Y, Zhu G, Wang G et al (2016) Robust glucose oxidase with a Fe3O4@C-silica nanohybrid structure. J Mater Chem B 4:47264731. https://doi.org/10.1039/c6tb01355d

23. Omoregie Al, Khoshdelnezamiha G, Senian N et al (2017) Experimental optimisation of various cultural conditions on urease activity for isolated Sporosarcina pasteurii strains and evaluation of their biocement potentials. Ecol Eng 109:65-75. https://doi. org/10.1016/j.ecoleng.2017.09.012

24. Whiffin VS (2004) Microbial $\mathrm{CaCO}_{3}$ precipitation for the production of biocement. PhD thesis, Murdoch University, Australia. https://researchrepository.murdoch.edu.au/id/eprin t/399/
25. Omoregie Al, Palombo EA, Ong DEL, Nissom PM (2019) Biocementation of sand by Sporosarcina pasteurii strain and technical-grade cementation reagents through surface percolation treatment method. Constr Build Mater 228:116828. https://doi. org/10.1016/j.conbuildmat.2019.116828

26. Cheng L, Cord-Ruwisch R, Shahin MA (2013) Cementation of sand soil by microbially induced calcite precipitation at various degrees of saturation. Can Geotech J 50:81-90. https://doi. org/10.1139/cgj-2012-0023

27. Fujita M, Nakashima K, Achal V, Kawasaki S (2017) Whole-cell evaluation of urease activity of Pararhodobacter sp. isolated from peripheral beachrock. Biochem Eng J 124:1-5. https://doi. org/10.1016/j.bej.2017.04.004

28. Stabnikov V, Naeimi M, Ivanov V, Chu J (2011) Formation of water-impermeable crust on sand surface using biocement. Cem Concr Res 41:1143-1149. https://doi.org/10.1016/j.cemco nres.2011.06.017

29. Chu J, Stabnikov V, Ivanov V (2012) Microbially induced calcium carbonate precipitation on surface or in the bulk of soil. Geomicrobiol J 29:544-549. https://doi.org/10.1080/01490 451.2011.592929

30. Moyo CC, Kissel DE, Cabrera ML (1989) Temperature effects on soil urease activity. Soil Biol Biochem 21:935-938. https://doi. org/10.1016/0038-0717(89)90083-7

31. ASTM D2487-17 (2017) Standard practice for classification of soils for engineering purposes (unified soil classification system). ASTM International, West Conshohocken

32. Gowthaman S, Mitsuyama S, Nakashima K et al (2019) Biogeotechnical approach for slope soil stabilization using locally isolated bacteria and inexpensive low-grade chemicals: a feasibility study on Hokkaido expressway soil, Japan. Soils Found 59:484-499. https://doi.org/10.1016/j.sandf.2018.12.010

33. Bolleter WT, Bushman CJ, Tidwell PW (1961) Spectrophotometric determination of ammonia as indophenol. Anal Chem 33:592594. https://doi.org/10.1021/ac60172a034

34. Japan Road Association (2009) Road earthworks: cut earthworks, earthquake, slope stabilization guidelines. Tokyo, Japan. ISBN13: 978-4889504156 (in Japanese)

35. Gowthaman S, Mitsuyama S, Nakashima K et al (2019) Microbial induced slope surface stabilization using industrial-grade chemicals: a preliminary laboratory study. Int J GEOMATE 17:110-116. https://doi.org/10.21660/2019.60.8150

36. JGS (Japanese Geotechnical Society) (2012) Method for needle penetration test (JGS: 3431-2012). In: Japanese standards and explanations of geotechnical and geoenvironmental investigation methods, No. 1. JGS Publication. Tokyo, pp 426-432 (in Japanese)

37. Ulusay R (2014) The ISRM suggested methods for rock characterization, testing and monitoring: 2007-2014. Springer, Berlin

38. Fukue M, Ono S-I, Sato Y (2011) Cementation of sands due to microbiologically-induced carbonate precipitation. Soils Found 51:83-93. https://doi.org/10.3208/sandf.51.83

39. Fukue M, Nakamura T, Kato Y (2001) A method for determining carbonate content for soils and evaluation of the results. Soils Found 49-2:9-12 (in Japanese)

40. Ciurli S, Marzadori C, Benini S et al (1996) Urease from the soil bacterium Bacillus pasteurii: immobilization on Ca- polygalacturonate. Soil Biol Biochem 28:811-817. https://doi. org/10.1016/0038-0717(96)00020-X

41. Mobley HL, Island MD, Hausinger RP (1995) Molecular biology of microbial ureases. Microbiol Rev 59:451-480

42. Jahns T (1992) Urea uptake by the marine bacterium Deleya venusta HG1. J Gen Microbiol 138:1815-1820. https://doi. org/10.1099/00221287-138-9-1815

43. Chen YYM, Anne Clancy K, Burne RA (1996) Streptococcus salivarius urease: genetic and biochemical characterization and 
expression in a dental plaque streptococcus. Infect Immun 64:585-592

44. Phang IRK, Chan YS, Wong KS, Lau SY (2018) Isolation and characterization of urease-producing bacteria from tropical peat. Biocatal Agric Biotechnol 13:168-175. https://doi.org/10.1016/j. bcab.2017.12.006

45. Bauerfeind P, Garner R, Dunn BE, Mobley HL (1997) Synthesis and activity of Helicobacter pylori urease and catalase at low pH. Gut 40:25-30

46. Martinez BC, DeJong JT, Ginn TR et al (2013) Experimental optimization of microbial-induced carbonate precipitation for soil improvement. J Geotech Geoenviron Eng 139:587-598. https:// doi.org/10.1061/(ASCE)GT.1943-5606.0000787
47. Cheng L, Shahin MA, Mujah D (2016) Influence of key environmental conditions on microbially induced cementation for soil stabilization. J Geotech Geoenviron Eng 143:04016083. https:// doi.org/10.1061/(asce)gt.1943-5606.0001586

48. Li H, Li C, Zhou T et al (2018) An improved rotating soak method for MICP-treated fine sand in specimen preparation. Geotech Test J 41:20170109. https://doi.org/10.1520/GTJ20170109

Publisher's Note Springer Nature remains neutral with regard to jurisdictional claims in published maps and institutional affiliations. 